\title{
Public Life as Tragedy
}

\author{
RICHARD D. FRENCH
}

\begin{abstract}
Some of the most perceptive observers of public life have emphasised its tragic dimensions, not so much out of sympathy for politicians, but because the lens of tragedy offers a unique insight into the realities of the world of politics. Here I attempt to synthesise this tragic perspective by employing the comments of those best positioned to identify the salient features of public life, its primary dramatis personae. Politics occasionally provides us with the kind of spectacular catastrophe that journalists like to construe as tragedy. But our purpose is to evoke a different, more personal, less visible kind of tragedy: the small but malignant tragedies of self-betrayal, of inflation of the ego and deflation of conscience, of helpless witness to injustice and misfortune, of status unaccompanied by power or efficacy, of the shrinking of aspiration to the scale of the practicable, of disillusion and, on occasion, of despair.
\end{abstract}

Keywords: rationalism, realism, tragedy, power, ideal theory, hypocrisy

THE FIRST modern author to leave us a realist description of public life, Machiavelli, wrote the following tercets sometime between 1507 and 1515, entitled 'On ingratitude or envy':

Line 166 Seek all the world's wide spaces; you will find few grateful princes, if you read what is written of them;

Line 169 and you will see shifters of governments and givers of kingdoms with death and exile always repaid ...

Line 181 Hence often you labor in serving and then for your good service receive a wretched life and violent death.

Line 182 So then, Ingratitude not being dead, let everyone flee from courts and governments, for there is no road that takes a man faster to weeping over what he longed for, when once he has gained it. ${ }^{1}$

A mere 400 years later, Max Weber offered the next great realist commentary on public life. Politics, as Weber saw it, is 'the strong and slow boring of hard boards', where only 'leaders and heroes' can achieve great things and 'those who are neither leaders nor heroes must arm themselves with that steadfastness of heart which can brave even the crumbling of all hopes'. ${ }^{2}$

Those who plot with princes, those who practice 'the strong and slow boring of hard boards', often find themselves 'weeping' over what they longed for, amid the 'crum- bling of all hopes': not an encouraging picture of the public career. There is a reason why two of the most perceptive students of the subject employ tragic images to convey the reality of public life. It is not because they wished to cultivate a climate of sympathy for its practitioners; it is because tragedy offers a more penetrating insight into the reality of the public charge than evocations of glory, dignity and honour or of corruption and careerism. It is not that either man denied the prospects and prerogatives of power; it is simply that they understood, more profoundly than most of their peers and successors to the present day, how fleeting those moments of triumph, how few become leaders and heroes, how costly such achievements, how unlikely-for most-the realisation of their hopes and ambitions. It is not that public life does not have its compensations; it is that those compensations are usually a set of worldly compromises which bear little relation to the ideals and idealisations which constitute the conventionally proffered accounts of what service to one's fellows in public office ought to resemble, and no more relation, on the other hand, to the cynical disparagement of politicians which passes for popular wisdom since Watergate and the other dispiriting chapters in the recent history of the Western democracies. 
In this article I want to explore how what has been called the 'lens of tragedy' offers insight into the realities of public life. I want to look at public life as tragedy, not in aid of gaining sympathy for politicians (or their constituents), not with the kind of comprehensive logic and semantic rigour characteristic of normative political theory, but rather as an approach which attempts to open the reality of public life for the benefit of those distant from it. I make no claim to completeness nor to the analytical standards of empirical political science, but I do claim verisimilitude.

Tragedy has been described as a realist category of thought, but perhaps 'trope' would have the literary overtones required in the minds of some theorists to do justice to the 'ambiguity and unresolved dilemmas' of public life, where 'poetry and drama may better capture the rhythms of action and so of politics than analysis, given the latter's epistemological assumptions and methodological endorsements'. ${ }^{3}$

\section{Public Life ...}

Politicians are from the people, but cannot remain of the people. Representation creates a gap, the quality of which determines the capital of the political agent. That is, the people and the politician interact, mostly indirectly, in such a way that each makes constantly adjusting evaluations of the other; as Machiavelli wrote, 'the people has a better understanding of the nature of princes than princes themselves, and the prince a better understanding of the people than the people itself' ${ }^{4}$ The rationalist takes this dependency to be the source of pathology: irrationality, populism, partisanry, demagogy. The realist sees it as the genius of democracy, harnessing ambition to popular sovereignty so that, as a senior Australian minister said, her prime minister had to be 'someone who each and every day knows he is going to get up and renew with the Australian people his trust and respect. . . so he's not taking anything for granted'. ${ }^{5}$

The French Prime Minister of 1913, Louis Barthou, put the same point another way:

A public man is ... a man who belongs to everyone. . . . We expect from him things we do not expect from anyone else ... He is a being apart. ... When a doctor has given his consultation or a lawyer has ended his plea, he has served his client and owes nothing to anyone. A politician always owes obligations, and he has the entire public for clientele. ${ }^{6}$

What is unique about this role is the constant evolution of public interest and expectations, in an environment filled with strategic actors responding to one another's cues, and to what they think may be the public's. Unlike any other profession or occupation, there is no job description for public life because there is no norm as to the substance and tenor of public opinion, not to mention the nature of the constituency, the strategic context and the qualities and traits of the representative.

Politicians work in a constantly unfolding kaleidoscope of events, personalities and issues, under conditions of omnipresent publicity, intense and unremitting competition and chronic uncertainty, where there is rarely enough time, information or leverage to accomplish goals. So much intervenes between the agent and his or her objectives, with so little on offer in the way of control over the instruments required. The AngloAmerican political journalist Henry Fairlie captured this superbly when he wrote: 'the politician in a free state is a potter who cannot choose his own clay, a painter who cannot mix his own paints, a composer who must compose for a brass band what he had perhaps intended for a string quartet. That is the measure of his $\operatorname{art}^{\prime} .7$ What does this mean for the political actor? 'Helplessness is what I hate, and the reality is, there is a fair amount of that in politics. ${ }^{8}$

\section{Publicity}

However hard she tries, the politician will always leave an impression above and beyond the one she is attempting to leave. Meaning is central to political action but it eludes the ultimate control of any politician, notwithstanding constant effort. Body language and non-verbal cues often speak louder than words. The media are omnipresent, essential and powerful: 'they are hostage to you and you are hostage to them. It's a sort of symbiotic dance that you do and it's difficult'. $^{9}$ 


\section{Competition}

Politicians live in a competitive environment comparable to that of professional athletes; someone always wants their place: 'Senators come to feel much like the chief of the Alban tribe, whom Frazer described in his Golden Bough as pacing at midnight in the grove by the Lake of Nemi, waiting for the rival who would slay him with a sword and then succeed to his chieftainship'. ${ }^{10}$

\section{Uncertainty}

Politics is the world of unpredictable events, disruptive strategies and unanticipated consequences. Another senator: 'But it's not the hard work or the long hours that wear you down, it's the uncertainty. You never know when there will be a crisis. . . ${ }^{\prime 1}$

Adaptation and improvisation-based more often than not on tacit knowledge or intuition-are the cardinal virtues in public life, not the mastery of codified knowledge, moral universals or disciplined dialogue. As Hampshire put it, 'The experience of political power is the experience of unplanned responses to emergency after emergency in constant succession'. ${ }^{12}$

Performance is more important than analysis. Orientation is more important than principle. The question is less 'should we go north?' and more 'where is the north?' It is this quality of barely controlled chaos, this lack of routine, this reframing of problems and reworking of nostrums in ever-changing circumstances, this succession of crises large and small which rationalists and idealists persist in perceiving as a sort of perpetual burlesque of the political, beyond which one might establish the real thing, if only a new kind of politician could be found or fabricated. They know what they would like this new politician to do, but they have no idea how to find him or her. The reality is, as Palonen concluded,

... the existential choice requires that a politician be a person who is willing and able to face a situation full of paradoxes with only partial knowledge of the horizon of available possibilities and with the constant presence of unanticipated consequences in political action. Nobody is obliged to choose to be a politician, but when one does choose to do so, one must understand the existential condition of this ideal typical figure. ${ }^{13}$

In such a world, the most useful knowledge is local, transitory or contingent, subject to feedback loops and strategic responses by other actors, rather than universal, abstract, timeless or epistemically sanctioned. Science and morality can be desirable; narrative and gossip ('political intelligence') are essential. 'Causal relations in politics are often an indeterminate morass'; ${ }^{14}$ 'the political world is hardly a Cartesian world, and the knowledge which the politician requires is not to be gained by Cartesian methods of study'. ${ }^{15}$ Misconceiving this feature of democratic politics can carry heavy penalties. The documentary filmmaker Erroll Morris said of Robert McNamara's policies in Vietnam: 'If he failed, it is because he tried to bring his idea of rationality to problems that were bigger and more deeply irrational than he or anyone else could rationally understand ${ }^{\prime 16}$ A realist might add that it was not that the problems in question were 'deeply irrational' so much as that they featured a rationality no rationalist could recognise.

\section{... as Tragedy}

Politics occasionally provides us with the kind of spectacular catastrophe that journalists like to construe as tragedy. But our purpose is to evoke a different, more personal, less visible kind of tragedy: the small but malignant tragedies of self-betrayal, of inflation of the ego and deflation of conscience, of helpless witness to injustice and misfortune, of status unaccompanied by power or efficacy, of the shrinking of aspiration to the scale of the practicable, of disillusion and, on occasion, of despair. The man or woman who emerges from a political career with an accurate sense of the disproportion between initial hopes and actual substantive achievement would be a person of exceptional self-awareness and extraordinary honesty. The testimony cited in what follows mostly consists of fragments which we may consider the issue of moments of candour whose recomposition here represents a whole greater than the sum of parts with which any politician would choose to construct an account of his or her career. This is no personal failure, but a natural psychological defence against a full 
accounting of the constraints and complications of public life. I want to emphasise that the purpose is not to portray public life as one without rewards, tangible and otherwise, but to weigh such a life on the scales which conventional conceptions of political achievement and service to the public weal might specify.

Politics brings out the best and the worst in people. It offers to a few, whose gifts and principles fit the moment, a kind of immortality closed to most of us-these are Weber's 'leaders and heroes', and they are few and far between. The overwhelming majority of public lives will fall rather short of this standard, but this is only trivially a product of personal shortcomings. More fundamentally, particular talents and commitments simply do not find their moment but rather collide, with greater or lesser friction, against the inexorable competition, uncertainty and complexity which history visits upon any public career. There is something arbitrary, something disconcertingly 'irrational' about this; idealists and rationalists find it impossible to swallow without choking on what they take to be its implications for the way we are governed. Their dismay is not difficult to understand, but it stands in the way of accurate insight into a democratic process of governing whose inherent contradictions and frustrations at the level of the individual mostly combine at the level of government into something resembling a positive vector sum-or, at least, do so better than any other system we have so far attempted. Democracy knows a wisdom which rationalism cannot perceive. That is why the title of this article is not 'Democracy as Tragedy'.

Why 'the crumbling of all hopes?' There are several species of tragedy in public life.

We can begin with the sheer difficulty of accomplishing anything. Political power withdraws infinitely just beyond the reach of the ambitious politician. Neal Blewett, a senior Australian cabinet minister in the 1990s, concluded that 'the closer one gets to what one thinks is power the more it seems to recede ${ }^{\prime}{ }^{17}$ Or, as an American congressman observed of himself and his colleagues, 'For all practical purposes, power doesn't keep people here. They come; they realize they don't have it'. ${ }^{18}$

In part, this is because we have designed democratic systems in this way. Constitutional constraints, the ever-multiplying agencies which regulate political life, the institutional complexity of the modern political economy and the partisan organisation of modern politics are such that most decisions are the vector sum of many hands over more or less prolonged periods of time, rather than the product of the integrity and judgement of a single political agent or small group at an identifiable moment in time.

The entropy which affects an electoral term is such as to sharply limit the potential leverage which any political agent possesses. To alter the metaphor, political capital has a very high discount rate. The democratic mandate erodes with every passing day. The frictional costs of governing mount up and the public tires of its choices. On average, an incumbent president loses about 0.5 per cent of the national vote every year. ${ }^{19}$ The elect do not feel so for very long. Anxiety follows rapidly upon euphoria.

Idealists and rationalists cherish the illusion that we need not settle for the adversarial, conflictual character of the compromised political life we (for them, inexplicably) tolerate. A more rational, consensual, efficient collective decision-making process could well outperform current practices of democracy (and better employ the talents of high-minded intellectuals of many stripes). But understanding this species of tragedy means understanding that there is no potential ideal politics behind the allegedly unedifying display which feeds the daily news. What we have seen in the democracies in the way of style and atmosphere is what we are likely to get.

Most often, the best one may hope for in public life would be avoidance of the worst, so that politics can do far less than the uninitiated imagine to render justice to the suffering. Goods may be incompatible. Settlements may be unstable. Persons may misunderstand one another. The pursuit of desirable ends is always compromised by the fragile mastery and unpredictable political costs of the available means. This is not an argument that effort is not worthy; it is an observation that progress comes slowly, not because of the incompetence of the political class-its failure to be attentive to enlightened opinion-but because of deeper-lying realities of democratic politics.

A second species of tragedy in public life is that democratic politics demands hypocrisy, economy with the truth, obfuscation of issues of prin- 
ciple, and personal relationships abraded by the ruthless and unpredictable exigencies of public obligation and private ambition. A politician must wear many masks and claim fellowship in many clans. He may end up unsure of his own identity and she may find herself unable to locate her own principles. A Canadian politician put it this way:

Every politician comes to the point where they know when they're making the decision to compromise their own principles for ambition. The danger in politics is not that you get to make that decision all at once. You have to make it a thousand times, step by step by step. And the challenge in politics is when you finally get to the one-thousandth decision, is there anything left in you? That's the truth of politics. You don't make one big compromise in politics. You make a thousand little ones. ${ }^{20}$

An American senator confessed, 'When I first ran for the Senate, _ told me that I would do and say things during the campaign that I would not recognize a year later ... You are going to be ashamed of yourself, he warned. And he was right.' ${ }^{21}$

As a junior minister, at the height of his political career, Chris Mullin was haunted by the relative superficiality of his knowledge of his ministerial files and by the existential angst the required charade occasioned:

None of these are subjects I know anything about. I live from hour to hour, never staying with any subject (except air traffic control) long enough to learn anything useful, praying that I can retain just sufficient information from the briefing to enable myself to bluff my way through without humiliation. As soon as it is no longer required, I press the mental delete button and the information is wiped from my mind, lost beyond recall. This is how it is every day ... I am beginning to lose my identity. Who am I? $?^{22}$

Probably the most acute dimension of this species of tragedy is that public life confronts its protagonists with a continuing and agonising pressure to treat people as means rather than as ends. This means that friends are as potentially dangerous as, or more so than, professed enemies. According to former Texas governor Ann Richards, 'I've always said that in politics, your enemies can't hurt you, but your friends will kill you. ${ }^{23}$ The danger is becoming, as Jack Straw said of Tony Blair, 'like a man who says "I love you" to seven, eight, nine, ten women and they all go away feeling happy until they start to compare notes'. ${ }^{24}$ Fallows notes of American presidents, 'Without exception, they betray their followersand must do so, to stay in office and govern' ${ }^{25}$

Finally, public life demands qualities of self-confidence and resilience which easily morph into less admirable traits such as arrogance or indifference. The illusion of political power is a standing temptation to hubris. Political staff, systematic deference, motorcades and front-row seats, queues jumped and doors opened, free tickets and diplomatic gifts: all this creates a bubble that erodes a politician's contact with his or her former quotidian life-the one in which his or her constituents are still living, the one that awaits his or her exit from politics. In the paradigm case of the Presidency of the United States, this accumulates to the point that, as George Reedy wrote, 'it is only a matter of months until they [staff and officials] become part of an environment which he necessarily regards as his just and due entitlement-not because of the office but because of his mere existence ... No one ever invites him to "go soak your head" when his demands become petulant and unreasonable'. ${ }^{26}$ (The wife of a leading Canadian politician jokes, 'What's the definition of a defeated politician? Somebody who gets into the back seat of a car and nothing happens ${ }^{\prime 27}$ )

Public office attracts so much criticism that politicians must develop a thick skin simply to endure. But when does a thick skin become an inability to empathise with the man in the street or the lady at the lunch counter? Tony Blair refers to the carapace of near indifference to dispute that is so dangerous in a leader yet so necessary for survival' ${ }^{28}$

Public life is a struggle to assume the burdens of representation without losing the reflexes of the represented, and to distinguish warranted criticism in the mass of disparagement and defamation.

The old saw is that most political lives end in failure. A public life has to end, and it usually ends in tears. A British minister observed that 'in the end we are all sacked and it's always awful. It is as inevitable as death following life. If you are elevated there comes a day when you are demoted'. ${ }^{29}$ In the mid-80s, Walter Mondale asked George McGovern how long it took him to get over his crushing defeat by Richard Nixon in 1972. 'I'll let you 
know when I get there', McGovern said. McGovern still had not gotten over losing twenty years later: 'There's no school of medicine that deals with that kind of [disappointment] ... You move on. But you carry what you did, that history, the rest of your life'.$^{30}$ Whether by forced resignation, demotion, electoral loss, or even voluntary departure, 'To leave positions of great responsibility and authority is to die a little', as Dean Acheson said on leaving office in $1952 .^{31}$

\section{Conclusion}

There is no lack of volunteers for public life, nor-elite and popular contempt notwithstanding - is there any evidence that politicians are somehow selected for intellectual or moral shortcomings. Ambition, altruism and narcissism ensure candidates are never lacking. The tragedy lies elsewhere, in fugitive consensus and the frustration of aspiration, in the contention and the obloquy, in the inevitable failures and unimaginable debacles for which the media provide the chorus and the population the bemused if not disillusioned audience. It lies in the discrepancy, rarely acknowledged, between the hopes of the neophyte politician and the accomplishments of the retiree. It lies, in short, in the inevitable constraints on the exercise of power demanded by the constitutional government of a free society.

The task of political leadership, therefore, is neither the realisation of abstract principle nor the application of epistemically sanctioned knowledge-though either may be of help from time to time-but rather the preservation of the tenuous rolling compromise which links the members of the political community in question. Keeping the ship of state more or less afloat, propelling it in more or less consistent directions, or proposing alternatives to those currently charged with that responsibility are the pre-eminent political tasks, and emotion, rather than reason, will be the dominant faculty engaged.

It is the mutual symbiosis of public office and popular constituency which seems so difficult for many members of the academy and the more high-minded parts of the commentariat to grasp. Any politician doing a credible imitation of the forms of rationality constituting the regulative ideal for academic life or editorial board will be quickly disabused by popular incomprehension. Calls by the proponents of worthy causes for 'political will' are an infallible sign of this inability to grasp the dynamics of democratic politics. They imagine that their frustrations are the product of personal indifference or irresponsibility on the part of the political class, when in fact they are simply a failure to understand that political actors encounter true believers of every intellectual dimension and worthy commitment every day.

Probably the most we can expect from democratic policy making is a continuous, Sisyphean effort to entrench a collective sense of mutual responsibility among citizens, embodied in policies responsive to collective well-being. 'Politics and policy making thus are not simply about finding solutions for pressing problems, but are as much about finding formats that generate trust among mutually interdependent actors', ${ }^{32}$ so that they offer ways 'to create communities that will be more than neutral sites for brokering self-interest' ${ }^{33}$

The story of democratic public life is not a set of homilies about virtue and vice, or reason and unreason. It is rather like an unending roman fleuve with all the ambiguity, the admixture of strength and weakness, the tragedy and the comedy of human life, the rollercoaster of public opinion and economic fortune and the personal vicissitudes which accompany the aura of power and the gravamen of the public charge.

To enter public life is to assume a tragic burden, guaranteed to disappoint those who repose their confidence in one. When, in 1896, the French parliamentary official Eugène Pierre published Politique et Gouvernement, he dedicated it to "The honored memories of all those legislators, from Moses until our own day, who suffered to govern their people and died without touching the Promised Land'. ${ }^{34}$ It seems appropriate that in concluding this article, I should follow his example.

\section{Acknowledgements}

The author would like to thank Ralph Heintzman and Alexandra Gheciu for their helpful insights and suggestions. 


\section{Notes}

1 Alan Gilbert, Machiavelli: The Chief Works and Others, vol. 2, Durham, Duke University Press, 1965, pp. 743-44.

2 http://www.goodreads.com/quotes/70587politics-is-a-strong-and-slow-boring-of-hardboards

3 J. Peter Euben, 'The tragedy of tragedy', in Toni Erskine and Richard Ned Lebow, eds., Tragedy and International Relations, Houndmills, Palgrave Macmillan, 2012, p. 91.

4 Quoted in Frank R. Ankersmit, Political Representation, Stanford, Stanford University Press, 2002, pp. 216-17.

5 Quoted in Anne Tiernan and Patrick Weller, Learning to be a Minister: Heroic Expectations, Practical Realities, Carlton, Melbourne University Press, 2010, p. 210.

6 Louis Barthou, Le Politique, Paris, Hachette, 1923, 6. Translation by the author.

7 Henry Fairlie, The Life of Politics, New York, Basic Books, 1968, p. 23.

8 Steve Paikin, The Dark Side: The Personal Price of Politics, Toronto, Penguin Canada, 2004, p. 253.

9 Tiernan and Weller, Learning to be a Minister, p. 220.

10 Donald R. Matthews, U.S. Senators and Their World, New York, Vintage, 1960, p. 76.

11 Matthews, U.S. Senators and Their World, p. 80, emphasis in the original.

12 Stuart Hampshire, Justice is Conflict, Princeton, Princeton University Press, 2000, p. 73.

13 Kari Palonen, The Struggle with Time: A Conceptual History of 'Politics' as an Activity, Münster, LIT Verlag, 2006, p. 191.

14 Russell Hardin, Indeterminacy and Society, Princeton, Princeton University Press, 2003, p. 113.

15 Fairlie, The Life of Politics, p. 203.

16 Quoted in Sandford Borins, Governing Fables: Learning from Public Sector Narrative, Charlotte, Information Age Publishing, 2011, p. 208.

17 Neal Blewett, A Cabinet Diary: A Personal Record of the First Keating Government, Kent Town, Wakefield Press, 1999, p. 206.

18 Burdett Loomis, The New American Politician: Ambition, Entrepreneurship, and the Changing Face of Political Life, New York, Basic Books, 1990, p. 243.

19 Samuel Popkin, The Candidate: What it Takes to Win - and Hold - the White House, New York, Oxford University Press, 2012, p. 198.

20 Paikin, The Dark Side: The Personal Price of Politics, p. 253.

21 Matthews, U.S. Senators and Their World, p. 74, emphasis in the original.

22 Chris Mullin, A View from the Foothills: The Diaries of Chris Mullin, London, Profile Books, 2010, pp. 53-4.

23 Quoted in Paikin, The Dark Side, p. 1.

24 Chris Mullin, Decline and Fall: Diaries 2005-2010, London, Profile Books, 2011, p. 19.

25 James Fallows, 'Obama, explained', The Atlantic, March 2012.

26 Quoted in Popkin, The Candidate, p. 138.

27 Paikin, The Dark Side, p. 100.

28 Tony Blair, A Journey: My Political Life, London, Random House, 2010, p. 30.

29 Alan Clark, Diaries, London, Phoenix/Orion, 1993, p. 14.

30 Quoted in Popkin, The Candidate, p. 261.

31 Jonathan Green, ed., The Book of Political Quotes, New York, McGraw-Hill, 1982, p. 143.

32 Maarten Hajer, 'Policy without polity: policy analysis and the institutional void', Policy Sciences, vol. 36, 2003, pp. 175-95, at p. 184.

33 Robert Hariman, 'Prudence in the twenty-first century,' in Robert Hariman, ed., Prudence: Classical Virtue, Postmodern Practice, University Park, Pennsylvania State University Press, 2003, p. 290.

34 Eugène Pierre, Politique et Gouvernement, Paris, Librairies-Imprimeries Réunies, 1896, frontispiece. Translation by the author. 